\title{
Ritka előfordulású, nagy méretú mellékvese-haemangioma sikeres sebészi kezelése
}

\author{
Ottlakán Aurél dr. ${ }^{1}$ - Paszt Attila dr. ${ }^{1}$. Tiszlavicz László dr. ${ }^{2}$ \\ Vas Márton dr. ${ }^{1}$ - Vass Csenge oh. ${ }^{3}$ - Lázár György dr. ${ }^{1}$ \\ 'Szegedi Tudományegyetem, Általános Orvostudományi Kar, Sebészeti Klinika, Szeged \\ ${ }^{2}$ Szegedi Tudományegyetem, Általános Orvostudományi Kar, Pathologiai Intézet, Szeged \\ ${ }^{3}$ Szegedi Tudományegyetem, Szeged
}

\begin{abstract}
A mellékvese-haemangiomák ritkán előforduló, nehezen diagnosztizálható elváltozások, melyek sebészi eltávolítása gyakran nagy fokú technikai jártasságot igényel. Vizsgálatunkban egy 69 éves nőbeteg esetét ismertetjük, akinél fogyás és hypertonia miatt végzett kivizsgálás mellékvesecisztát feltételezett, valamint felvetette adrenocorticalis carcinoma jelenlétét. A preoperatív kivizsgálás során (CT és $\mathrm{MRI}$ ) a felmerülő malignitás miatt sebészi eltávolítás vált szükségessé. A kezdeti laparoszkópos transperitonealis technikát követően a bonyolult elhelyezkedés, illetve vérzés miatt kis méretű, paramedián metszésből konvertáltunk, és bal oldali nyitott adrenalectomiát végeztünk, valamint a vese caudalis részéról egy folyadéktartalmú képletet távolítottunk el. A szövettani feldolgozás a vese középső harmadának magasságából reszekált cisztát, valamint a cranialis lokalizációról eltávolított, ritka előfordulású mellékvesehaemangiomát igazolt. A ritkán előforduló és többnyire bizonytalan preoperatív diagnózissal bíró mellékvesehaemangiomák sebészi eltávolítása nagy méretük, kompresszióra való hajlamuk, valamint malignitást utánzó megjelenésük miatt is indokolt. A laparoszkópos transperitonealis adrenalectomia extra nagy méretû (>10 cm ) és malignus tumorok, illetve nagy méretű haemangiomák eltávolítására is alkalmas eljárás. A mellékvese-haemangiomák sebészi reszekciója nagyfokú körültekintést igényel, megnövekedett vérzéshajlamuk, valamint a gyakori, nagyerekhez való közeli elhelyezkedés miatt a konverzió veszélye is jelentősen növekszik.
\end{abstract}

Orv Heti. 2020; 161(47): 2006-2010.

Kulcsszavak: mellékvese, haemangioma, adrenalectomia

\section{Successful surgical treatment of a rare, large adrenal hemangioma}

Adrenal hemangiomas are rare. Their preoperative diagnosis is usually vague, and often require advanced surgical skills for resection. We herein describe the case of a 69 -year-old female patient initially presented with weight loss and hypertension. Preoperative Computed Tomography (CT) and magnetic resonance imaging (MRI) confirmed the presence of an adrenal cyst and possible adrenocortical carcinoma requiring surgical intervention. After initial laparoscopic transperitoneal approach, conversion to open surgery through a small paramedian incision was carried out due to the lesion's problematic location and continuous intraoperative bleeding. Open adrenalectomy along with the removal of a fluid-bearing lesion from the caudal pole of the kidney was performed. Histology confirmed a cyst removed from the mid-third, and a rare occurring adrenal hemangioma from the cranial part of the kidney. Adrenal hemangiomas usually bear uncertain preoperative diagnosis. Surgical removal becomes necessary in case of increasing size, potential to compress neighbouring structures and possible malignancy. Laparoscopic transperitoneal adrenalectomy is a feasible approach for the removal of extra large $(>10 \mathrm{~cm})$ and even malignant lesions as well as for large hemangiomas. Surgery of adrenal hemangiomas require a high level of caution, moreover, their potential for bleeding and frequent vicinity to nearby vascular structures may increase the need for open surgery.

Keywords: adrenal gland, hemangioma, adrenalectomy

Ottlakán A, Paszt A, Tiszlavicz L, Vas M, Vass Cs, Lázár Gy. [Successful surgical treatment of a rare, large adrenal hemangioma]. Orv Hetil. 2020; 161(47): 2006-2010.

(Beérkezett: 2020. május 7.; elfogadva: 2020. június 1.) 


\section{Rövidítések}

$\mathrm{CT}=$ (computed tomography) számítógépes tomográfia; $\mathrm{MRI}=$ (magnetic resonance imaging) mágnesesrezonancia-képalkotás

A haemangiomák jóindulatú érdaganatok, melyek fóként a májban, illetve bőrlaesiók formájában fordulnak elő. A ritka manifesztációk közé tartoznak a mellékvese kéreg- vagy velőállományában elhelyezkedő haemangiomák. Definitív diagnózisuk többnyire csak hisztopatológiai feldolgozás során állítható fel, mivel a preoperatív azonosítás számos akadályba ütközhet (a típusos tünetek hiánya, képalkotókon aspecifikus megjelenés) [1]. Sebészi eltávolításuk indokolt lehet vérzés, kompressziós tünetek, illetve felmerülő malignitás esetén. Mütéti eltávolításuk lehetséges minimálisan invazív (laparoszkópos) úton is, azonban a gyakran bonyolult elhelyezkedésük és az intraoperatív vérzés megnövekedett kockázata miatt gyakran nyitott mútét elvégzése válik szükségessé. A preoperatív diagnosztika fontos részét képezi a közelben elhelyezkedő (ér)struktúrák és a haemangioma elhelyezkedésének pontos tisztázása (CT, MRI), mely a sebészeti beavatkozás kimenetelét is jelentősen befolyásolhatja.

\section{Esetismertetés}

Egy 69 éves nőbeteg esetét vizsgáltuk, akinél supraventricularis extrasystolék, hypertonia, valamint bizonytalan jellegű hasi fájdalom miatt kezdődött kivizsgálás. Anamnézisében 18 évvel korábban jobb oldali craniospinalis meningeoma (benignus) miatt történt mütét, majd 10 évvel később gamma-késsel stereotaxiás irradiáció, illetve 4 évvel ezt követően vascularis encephalopathia és vertebrobasilaris insufficientia miatt vazoaktív infúziós kezelés zajlott. A háziorvos időszakos szédülés, ingadozó magas vérnyomás miatt utalta belgyógyászati osztályra. Anamnézisében a korábban leírtakon túl jelentős fogyás is szerepelt, így gasztroenterológiai kivizsgálás is szükségessé vált. A gasztroszkópia erozív gastritist, valamint a

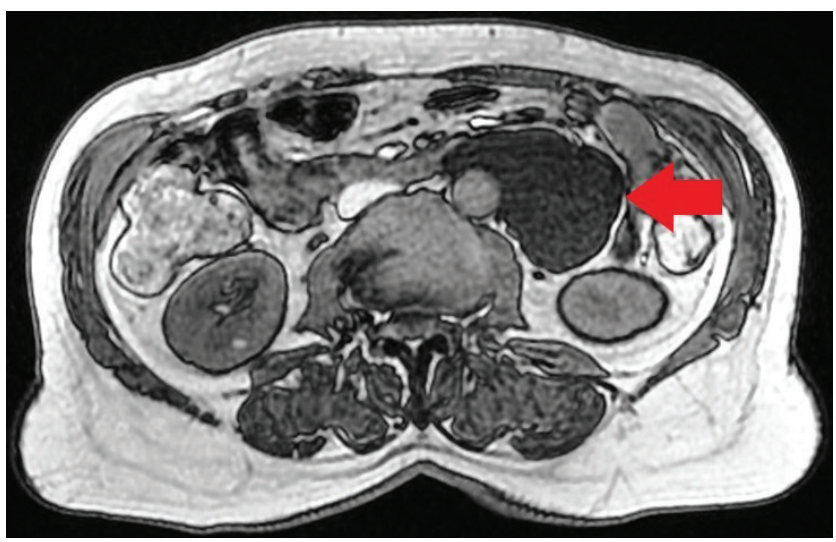

1. ábra

Horizontális, Tl-súlyozott MRI, a bal mellékveséből kiinduló haemangiomával (piros nyíl)

MRI = mágnesesrezonancia-képalkotás gyomorcorpusban kis méretú polipot véleményezett, melynek biopsziás mintájában malignitás nem, azonban idült Helicobacter pylori infekció asszociált gastritis igazolódott, melynek eradikációja megtörtént. A kolonoszkópia kóros eltérést nem igazolt. A hasi ultrahangvizsgálat a bal vese középső harmadában egy 18 mm-es, illetve attól caudalisan egy, a köldök magasságában elhelyezkedő, különálló, 68 × 50 mm-es tömlős képletet írt le. A laesiók pontosabb megítélésére kontrasztanyagos hasi CT készült, mely a bal vese magasságában, a bal oldali mellékvese laterális szárával összefüggően az aortát körülölelő, $70 \times 7,45 \mathrm{~mm}$ nagyságú, kontrasztanyagot inhomogénen halmozó, szivacsos terimét írt le, mely diszkréten infiltrálta a környező zsírszövetet. Mindezek alapján az elváltozások pontosabb megítélésére MRI készült. Az MRI során egy, a hasi aorta szomszédságában, a bal vese alsó harmada előtt elhelyezkedő, 60 mm-es folyadéktartalmú képletet (1. ábra), illetve attól cranialisan, a bal vese felsó pólusa előtt elhelyezkedóen és a bal mellékvesével összefüggően egy 20 mm-es, szöveti jeladású képletet írtak le, melyek felvetették adrenocorticalis carcinoma lehetőségét (2. ábra). Egyik képlet eseté-

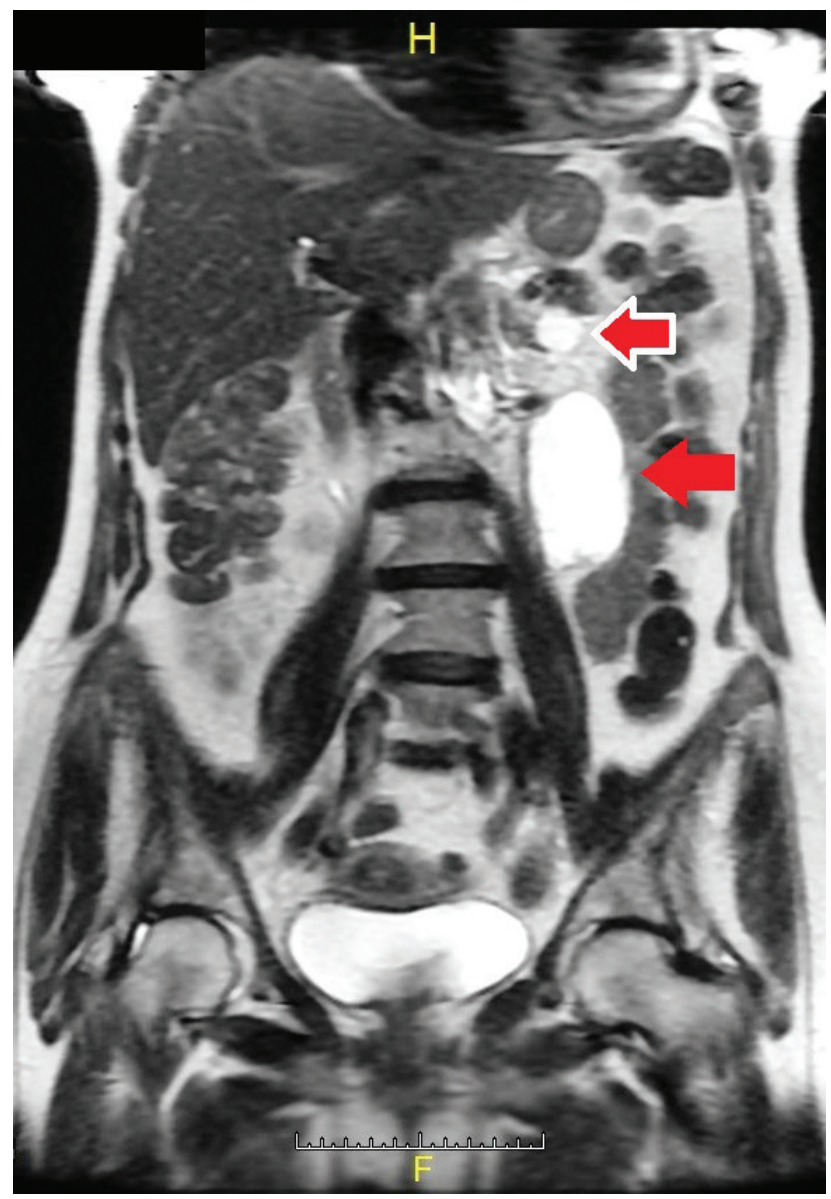

2. ábra

Koronális, T2-súlyozott MRI; a vese felsó pólusánál elhelyezkedő, a bal mellékveséból kiinduló haemangioma (piros-fehér nyíl), valamint a caudalisabban elhelyezkedő pseudocysta (piros nyíl)

MRI = mágnesesrezonancia-képalkotás 
ben sem írtak le egyértelmú összefüggést a vesével, azonban a cranialis helyzetû laesio mellékvese-eredetét véleményezték. Az endokrinológiai kivizsgálás az elváltozások hormonális aktivitását nem igazolta. Mindezek alapján mütét elvégzését javasolták.

A laparoszkópos transperitonealis technikával végzett mútét során, a bal colonfél mobilizálását követően, a bal mellékvese magasságában felkerestük az aorta szomszédságában elhelyezkedő szolid elváltozást, mely laparoszkópos manipulálás során a vese felső pólusához szívósan rögzült, preparálás során igen vérzékenynek bizonyult, ezért kis méretű paramedián metszésből konverzióra kényszerültünk. Nyitott technikával reszekáltuk a szolid képletet, valamint preparálás során a vese alsó pólusánál, a duodenojejunalis áthajlás közelében megtaláltuk és el-

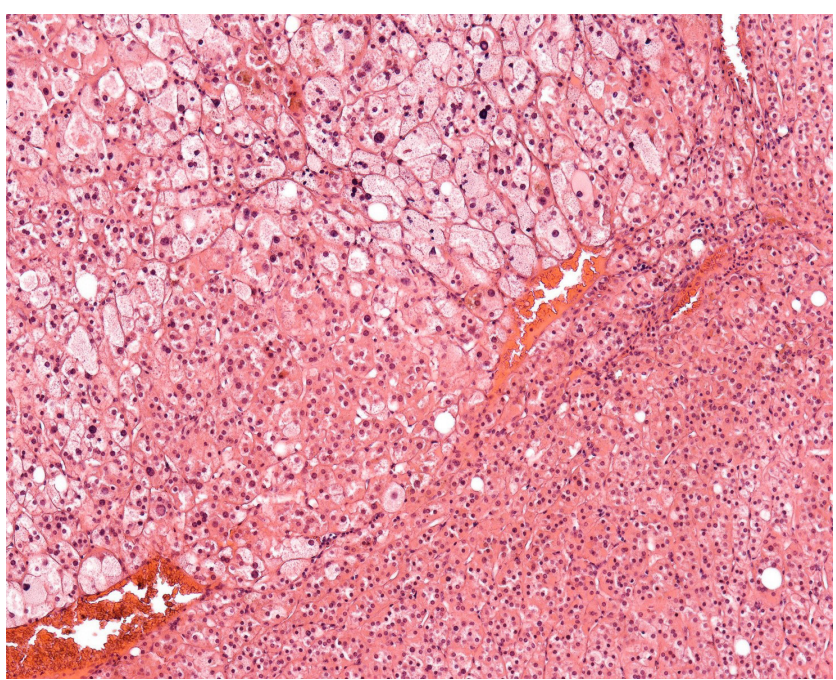

3. ábra

A mellékvese körüli szövet, fibroticus alapállományban kapilláris jellegű haemangioma, bevérzéssel (HE, 10×)

$\mathrm{HE}=$ hematoxilin-eozin

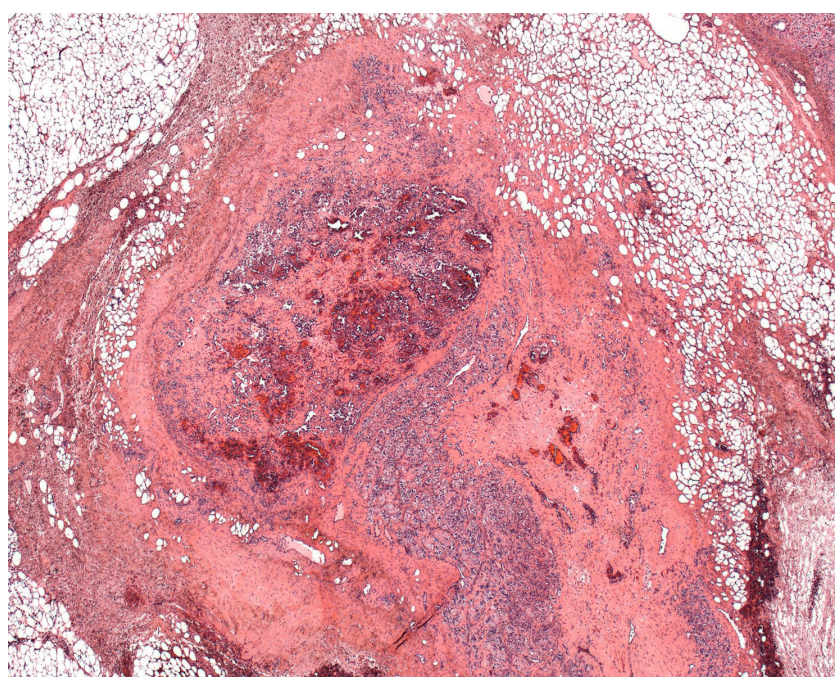

4. ábra

Mellékvesekéreg-adenoma (ép-kóros határ; HE, 20×

$\mathrm{HE}=$ hematoxilin-eozin távolítottuk a kb. almányi, folyadéktartalmú képletet. A posztoperatív szakban a beteg állapota stabil volt, utóvérzés nem jelentkezett. A per os táplálást fokozatosan felépítettük. A passzázs megindult. A beteg a 6 . posztoperatív napon jó általános állapotban otthonába távozott.

A szövettani feldolgozás során a vese felső pólusában a mellékveséból kiinduló, $55 \times 23 \times 14$ mm-es haemangiomát, egy $9 \mathrm{~mm}$ legnagyobb átmérőjü kéregadenomát, valamint ettől caudalisan elhelyezkedő, $45 \times 23 \times 8 \mathrm{~mm}$ es retroperitonealis pseudocystát véleményeztek (3. és 4. ábra).

\section{Megbeszélés}

A mellékvese-haemangiomák viszonylag ritkán előforduló, többnyire posztoperatív szövettani feldolgozás során igazolt elváltozások. Az első ilyen elváltozást 1955-ben publikálták; azóta mintegy 70 esetről tudósítottak [2], amiből következtetni lehet a kórkép relatív ritka előfordulására. Magyar vonatkozású publikációról mindeddig nem volt tudomásunk, így saját klinikai anyagunk alapján elsőként adódott lehetőségünk ezen entitás közlésére.

A mellékveséból kiinduló haemangiomák a mellékvesetumorok 0,01\%-át képezik [3]. Az utóbbi években a képalkotó diagnosztika fejlődésének köszönhetően gyakrabban azonosítják őket, valószínúsíthetően a mind gyakrabban alkalmazott és széles körben elterjedt CT- és MR-vizsgálatoknak köszönhetően. A képalkotás során a mellékvese-haemangiomák sok esetben aspecifikus megjelenésűek, ezzel is bonyolítva a preoperatív diagnózist. A legpontosabban kontrasztos MRI során azonosíthatók, sok esetben azonban az MRI sem képes pontos diagnózist adni, mindössze szolid terimeként írja le az elváltozást [4]. Egyes esetekben mikrokalcifikációk láthatók, máskor a haemangioma szegélye jelintenzíven, centrális jelintenzitás nélkül mutatkozik meg [5]. Az elváltozások 60\%-a mutat elszórtan kalcifikációt [1]. Saját esetünk során is hasonló nehézségek merültek fel, tekintve, hogy a hasi ultrahangvizsgálat mindkét laesiót leírta ugyan, ám csak az MRI tudott azok elhelyezkedéséról, pontos méretéról és struktúrájáról érdemben nyilatkozni. A meglévő helyzetet tovább nehezítette az a tény is, hogy a haemangioma mellett, attól függetlenül elhelyezkedő szivacsos képletet is véleményeztek, melyet a legpontosabban a hasi MRI írt le. A végleges szövettani eredmény szintén szokatlan elváltozások együttesét: egy mellékvese-haemangiomát, egy mellékvese-eredetű pseudocystát, valamint egy mellékvese-adenomát írt le, melyek együttes előfordulását korábban a nemzetközi irodalomban sem találtuk meg. A mellékvese-pseudocysták igen ritka előfordulású, az összes mellékveseciszta kb. 40\%-át kitevő, többnyire hasi képalkotás során véletlenszerúen, incidentalomaként diagnosztizált elváltozások [6]. Etiológiájuk kétséges, egyes megfigyelések szerint a mellékvesében korábban bekövetkezett bevérzések maradványaként alakulnak ki [7], mely teória esetünkben 
összefüggést mutathat a haemangioma együttes jelenlétével. Differenciáldiagnosztikai szempontból szóba jöhetnek még epithelialis, endothelialis, illetve parazitás eredetú ciszták is [8]. Véralvadási zavarok, illetve magas dózisú heparintartalmú készítmények adása esetén a pseudocysták hajlamosak bevérezni és így főleg CT-felvételen megjelenésükben phaeochromocytomát, myelolipomát, áttétet, valamint adrenocorticalis carcinoma képét utánozni [7].

Habár nem nevezhető rutineljárásnak, haemangiomák gyanúja esetén szóba jöhet angiográfia elvégzése, mely a kontrasztanyag halmozása révén markáns, keretszerúen elhelyezkedő neovascularisatiót mutatva igazolhatja éreredetú elváltozás meglétét [6]. Gyakran azonban az érfestés eredménye sem specifikus haemangiomákra, mivel egyéb, éreredetû malformációkra is utalhat (angiolipoma, cavernosus haemangioma, epitheloid haemangioendothelioma) [6]. A mellékvese-haemangiomák 60-70 éves korban, többnyire nőknél fordulnak elő, és mindössze 5,8\%-ban mutatnak hormonális aktivitást [9]. Méretük az átlagos $10 \mathrm{~cm}$-tól egészen $30 \mathrm{~cm}$-ig terjedhet [3]. A laesiók a kéregállománytól többnyire jól elhatárolhatók, és típusosan gazdag vascularisatiót mutatnak, melyekben az ereket lapos endothelsejtekkel és fibrosus szövettel körülvett réteg szegélyezi. Belsejükben gyakran thrombusok és infarcerálódott területek is megtalálhatók, a régebb óta jelen lévő laesiók esetében kiterjedt fibrosissal és meszesedésekkel [10]. A mellékvese-haemangiomákra jellemző, hogy hosszú lappangási idővel, tünetmentesen növekszenek mindaddig, amíg kompressziós tüneteket nem okoznak, vagy képalkotók során nem detektálják azokat (incidentalomák). Jelenlétüket bizonytalan tünetek jelzik, úgymint unduláló láz, fogyás vagy profúz izzadás. A betegek többségénél hypertonia is jelen van [5]. A betegek többsége azonban panaszmentes, tünetek csak bizonyos méret elérését követően, a szomszédos struktúrák kompressziója következtében jelentkeznek; ritkábban tapintható terime is jelen van.

A sebészi reszekció elvégzése növekedést mutató, illetve malignitásra gyanús mellékvese-elváltozások esetében az endokrin aktivitástól függetlenül ajánlott [11]. A haemangiomák sebészi eltávolítása ajánlott malignomák kizárására, illetve nagyobb méret esetén a potenciális ruptura és a következményes haemorrhagiás állapot kialakulásának megelözésére, ez azonban irodalmi ritkaságnak számít [12]. A mútéti típus megválasztásában a laesiók eltávolítása során jól alkalmazható a minimálisan invazív, laparoszkópos transperitonealis módszer. A transperitonealis adrenalectomiák során, a hasi sebészek számára ismerős környezet mellett, a mellékvesék könnyen és gyorsan hozzáférhetők, a mütét 3-4 port alkalmazásával, alacsony vérveszteséggel, rövid mútéti idővel végezhető [13]. Nagyobb méretű specimen esetében a reszekált elváltozások jó kozmetikai eredményt és alacsony sérvkialakulási rátát jelentő paramedián vagy mini-Pfannenstiel-metszésből távolíthatók el. A transperitonealis módszer a $6 \mathrm{~cm}$ feletti, illetve malignus tumorok ese- tében is biztonsággal, az onkológiai irányelveknek maradéktalanul eleget téve alkalmazható [14]. Annak ellenére, hogy napjainkban a minimálisan invazív adrenalectomia arany standardnak tekinthető, ritka megjelenésü, fragilis struktúrájú, nagy fokú vérzést mutató elváltozásoknál konverzió válhat szükségessé. Mellékvese-haemangiomák esetében a mütét során észlelt nagyobb ütemû vérzés, illetve a laparoszkópos manipuláció nehézségei miatt a célravezető megoldás a jól megválasztott és aránylag kis méretú metszésból kivitelezett nyitott reszekció, mely a komplett reszekciót és a beteg számára a legelfogadhatóbb megterhelést jelenti.

Esetünkben egy $4 \mathrm{~cm}$-es, fokozatos méretbeli növekedést mutató mellékvese-haemangiomát távolítottunk el sikeresen, laparoszkópos kezdést követően, nyitott technikával. Habár a haemangiomák a mellékvese-elváltozások viszonylag kis részét képezik, mégis differenciáldiagnosztikai jelentőséggel bírnak. Tekintettel arra, hogy képalkotás során a kórkép gyakran nem identifikálható biztonsággal, a növekedést mutató elváltozások sebészi eltávolítása a malignitás kizárására, valamint a potenciális ruptura megelőzésére javasolt; ez alapvetően benignus megjelenésük miatt laparoszkóposan elvégezhető, szem előtt tartva, hogy amennyiben a minimálisan invazív módszer bármilyen technikai nehézségbe ütközik, nyitott mütét elvégzése ajánlott.

Anyagi támogatás: A közlemény megírása, illetve a kapcsolódó kutatómunka anyagi támogatásban nem részesült.

Szerzôi munkamegosztás: O. A.: A kézirat megírása, kutatómunka. P. A.: Szakmai véleményezés, tanácsadás. T. L.: A patológiai rész szakmai véleményezése. V. M., V. Cs.: Irodalomkutatás. L. Gy.: A kézirat szakmai véleményezése, a kutatómunka koordinálása. A cikk végleges változatát valamennyi szerző elolvasta és jóváhagyta.

Érdekeltségek: A szerzóknek nincsenek érdekeltségeik.

\section{Irodalom}

[1] Ojili V, Tirumani SH, Gunabushanam G, et al. Abdominal hemangiomas: a pictorial review of unusual, atypical, and rare types. Can Assoc Radiol J. 2013; 64: 18-27.

[2] Johnson CC, Jeppesen FB. Hemangioma of the adrenal. J Urol. 1955; 74: 573-577.

[3] Zemni I, Haddad S, Hlali A, et al. Adrenal gland hemangioma: a rare case of the incidentaloma. Case report. Int J Surg Case Rep. 2017; 41: 417-422.

[4] Hashimoto A, Yoshino H, Yoshikawa F, et al. Giant cavernous hemangioma of the adrenal gland in an elderly patient. Intern Med. 2018; 57: 1317-1319.

[5] Yamada T, Ishibashi T, Saito H, et al. Two cases of adrenal hemangioma: CT and MRI findings with pathological correlations. Radiat Med. 2002; 20: 51-56.

[6] Ottlakan A, Paszt A, Simonka Zs, et al. Laparoscopic transperitoneal and retroperitoneal adrenalectomy: a 20 -year, single-institution experience with an analysis of the learning curve and tumor 


\section{ESETISMERTETÉS}

size [lap transper and retroper adrenalectomy]. Surg Endosc. 2020 Jan 17. https://doi.org/10.1007/s00464-019-07337-1 [Online ahead of print]

[7] Kawashima A, Sandler CM, Ernst RD, et al. Imaging of nontraumatic hemorrhage of the adrenal gland. Radiographics 1999; 19: 949-963.

[8] Patnaik S, Htut A, Wang P, et al. All those liver masses are not necessarily from the liver: a case of a giant adrenal pseudocyst mimicking a hepatic cyst. Am J Case Rep. 2015; 16: 333-337.

[9] Quint LE, Glazer GM, Francis IR, et al. Pheochromocytoma and paraganglioma: comparison of MR imaging with CT and I-131 MIBG scintigraphy. Radiology 1987; 165: 89-93.

[10] Maestre-Maderuelo M, Candel-Arenas M, Terol-Garaulet E, et al. Laparoscopic adrenalectomy: the best surgical option. [Suprarrenalectomia laparoscópica: la mejor opción de tratamiento quirúrgico.] Cir Cir. 2013; 81: 196-201. [Spanish]
[11] Forbes TL. Retroperitoneal hemorrhage secondary to a ruptured cavernous hemangioma. Can J Surg. 2005; 48: 78-79.

[12] Noh JJ, Choi SH, Hwang HK, et al. Adrenal cavernous hemangioma: a case report with review of the litreature. Pancreas (Online) 2014; 15: 254-257.

[13] Harzallah L, Zouari L, Ben Chérifa L, et al. Adrenal hemangioma: a case report. [Hémangiome surrénalien: à propos d'un cas.] Ann Endocrinol (Paris). 2006; 67: 624-627. [French]

[14] Feo CV, De Troia A, Pedriali M, et al. Adrenal cavernous hemangioma: a case report. BMC Surg. 2018; 18: 103.

(Lázár György dr., Szeged, Semmelweis u. 8., 6725 e-mail: lazar.gyorgy@med.u-szeged.hu)

\section{"Auxilia humilia firma consensus facit." (Szerény eszközöket is erőssé tesz az egyetértés.)}

A cikk a Creative Commons Attribution 4.0 International License (https://creativecommons.org/licenses/by/4.0/) feltételei szerint publikált Open Access közlemény, melynek szellemében a cikk bármilyen médiumban szabadon felhasználható, megosztható és újraközölhető, feltéve, hogy az eredeti szerző és a közlés helye, illetve a CC License linkje és az esetlegesen végrehajtott módosítások feltüntetésre kerülnek. (SID_1) 